\title{
In vitro Anti-Proliferative and Antioxidant Activities of Stem Extracts of Pereskia bleo (Kunth) DC (Cactaceae)
}

\author{
Hong Lim Lee', Hui Meng $\mathrm{Er}^{2^{*}}$ and Ammu Kutty Radhakrishnan ${ }^{3}$ \\ ${ }^{1,2,3}$ Faculty of Medicine and Health, International Medical University, No.126 Jalan 19/155B, Bukit Jalil, 57000 \\ Kuala Lumpur, Malaysia. *huimeng_er@imu.edu.my (corresponding author) \\ Received on $22^{\text {nd }}$ June 2009, accepted in revised form $30^{\text {th }}$ September 2009.
}

\begin{abstract}
Pereskia bleo (Kunth) DC (Cactaceae) (Pereskia bleo) is a tropical plant that has been reported to possess cytotoxic acitivity against several human cancer cell lines. This study was carried out to investigate the in vitro anti-proliferative and antioxidant activities of the stem extracts of the plant. All extracts did not show significant anti-proliferative activity in both normal mouse fibroblast (NIH/3T3) and mouse mammary cancer (4T1) cell lines. There was an increased rate of proliferation when the 4T1 cells were co-cultured with these extracts under certain conditions. Among the extracts, the $t$-butanol extract had the highest antioxidant property. All the extracts had the ability to protect normal mouse fibroblast cells against natural and oxidant-induced cell death by apoptosis.
\end{abstract}

\begin{abstract}
ABSTRAK Pereskia bleo (Kunth) DC (Cactaceae) (Pereskia bleo) ialah sejenis tumbuhan tropika yang dilaporkan mengandungi aktiviti sitotoksik terhadap beberapa jenis sel kanser manusia. Pengajian ini dijalankan untuk memeriksa aktiviti anti-proliferatif dan anti-oksidan dalam ekstrak-ekstrak dari batang tumbuhan ini. Kesemua ekstrak yang dikajikan tidak mempunyai aktiviti anti-proliferatif yang signifikan terhadap sel jenis normal mouse fibroblast (NIH/3T3) dan mouse mammary cancer (4T1). Kadar proliferasi sel 4T1 bertambah apabila ianya dikultur dengan ekstrak-ekstrak ini di bawah keadaan yang tertentu. Di antara ekstrak-ekstrak ini, ekstrak dari $t$ butanol mempunyai aktiviti anti-oksidan yang tertinggi. Kesemua ekstrak ini boleh mempertahankan sel NIH/3T3 daripada kematian apoptosis yang berlaku secara semulajadi atau diakibatkan oleh bahan oksidan.
\end{abstract}

(Keywords: Pereskia bleo, anti-proliferative, antioxidant, oxidant-induced cell death, apoptosis.)

\section{INTRODUCTION}

In the $21^{\text {st }}$ century, cancer is considered as a social disease of high mortality and morbidity, and is highly associated with environmental pollutants. Despite advances in medical research and technology, the prevention and treatment for cancer are still not clearly defined. Currently, there are many anti-cancer drugs that are available in the market. However, the effectiveness of these drugs is very much dependent on the cancer type, stage of the disease and individual variability. Some of these drugs have serious side effects. Therefore, there is a need for continuing effort in the development of new anti-cancer drugs that have higher therapeutic efficacy and less adverse side effects.

Pereskia bleo (Kunth) DC (Cactaceae) (Pereskia bleo) is a tropical plant that is commonly consumed by some ethnic groups in Malaysia for its medicinal properties. It is claimed by the local folks to have curative effects for diseases such as diabetes and hypertension [1]. There are also claims that Pereskia bleo can be used to prevent and treat cancer. The methanol extract from the combined stems and leaves of Pereskia bleo has been shown to be cytotoxic against a human mammary cancer cell line, T47-D [2]. Moreover, the crude methanol extract and the ethyl acetate fraction of the plant leaves have been shown to possess high cytotoxic effect against the human nasopharyngeal epidermoid carcinoma cell line (KB) [3]. These findings suggest that the plant may be a potential candidate that can be developed for cancer treatment. However, another study has shown that the methanol and aqueous extracts of the leaves of this plant did not exhibit significant antiproliferative properties against the mouse mammary cancer cell line (4T1) and normal mouse fibroblast cell line (NIH/3T3) [4]. The inconsistent findings could be due to the different cell lines used. It is also possible that different parts of the plants contain different bioactive constituents.

The plant morphology of Pereskia bleo is unique, as the stems are covered with spines, which are arranged in groups of seven on each areole. These are thought to contribute to the plant's natural defence against pests and herbivores. It is well known that many 
plants contain secondary metabolites that have important medicinal properties. Among these, Paclitaxel is an effective anti-cancer agent isolated from the yew species. In view of the unique features of the plant stems, this study was carried to evaluate the anti-proliferative and antioxidant properties of its stem extracts.

\section{MATERIALS AND METHODS}

\section{Preparation of extracts}

The Pereskia bleo plant cuttings were collected from Taman Pertanian of the Universiti Putra Malaysia, Serdang, Malaysia. The plant was authenticated by Dr. E. Soepadmo from the Forest Research Institute of Malaysia (FRIM), Selayang, Malaysia. The stems and the leaves of the plant were separated, cleaned with water and dried in a convection oven at $40^{\circ} \mathrm{C}$ until consistent weights were obtained. The dried stems were cut into smaller pieces and blended into powder form using an electric blender. A weighed amount $(20 \mathrm{~g})$ of the stem powder of Pereskia bleo was extracted with methanol $(250 \mathrm{~mL})$ using a soxhlet extractor for four hours. The process was repeated five times and the extracts were combined. The methanol solvent in the combined extract was removed under reduced pressure at $40^{\circ} \mathrm{C}$ using a rotary evaporator and the extract was further dried using a vacuum concentrator at $40^{\circ} \mathrm{C}$ until a consistent weight. A portion of the methanol extract was further fractionated by sequential partitioning into ethyl acetate, $t$-butanol and water. The solvents in these fractionated extracts were removed under reduced pressure at $40^{\circ} \mathrm{C}$ using a rotary evaporator. The ethyl acetate and $t$-butanol extracts were further dried to consistent weights using a vacuum concentrator at $40^{\circ} \mathrm{C}$. The aqueous extract was freeze-dried to a consistent weight. The yields of the methanol, ethyl acetate, $t$-butanol and aqueous extracts were $12.4 \%, 0.5 \%, 0.6 \%$ and $8.5 \%$, respectively, based on the dry weight of the stem.

\section{Cell proliferative assay}

Cell proliferation was analysed using the MTT assay [5]. This assay is based on the ability of the mitochondria of living cells to reduce a chemical, 3(4, 5-Dimethylthiazol-2-yl)-2, 5-diphenyltetrazolium bromide (MTT), which is a yellow tetrazolium salt, to purple formazan product that is insoluble in the aqueous phase.

The NIH/3T3 (normal mouse fibroblast cell line) and 4T1 (mouse mammary cancer cell line) cells were purchased from the American Type Culture Collection (ATCC, Rockville). They were cultured in RPMI 1640 medium containing L-glutamine and supplemented with 10\% FBS, 1\% HEPES buffer solution, $1 \%$ sodium pyruvate $(100 \mathrm{mM})$ and $0.5 \%$ penicillin-streptomycin (GIBCO, Invitrogen Corp., New Zealand) in a humidified $5 \% \mathrm{CO}_{2}$ incubator at $37^{\circ} \mathrm{C}$.

The NIH/3T3 or $4 \mathrm{~T} 1$ cells $\left(100 \mu \mathrm{L}, 5 \times 10^{3}\right.$ cells $)$ were added to each well of a sterile 96-well flat-bottom tissue culture plate (Nunc, Denmark). The plate was then incubated at $37^{\circ} \mathrm{C}$ in a humidified $5 \% \quad \mathrm{CO}_{2}$ incubator for 2 hours. During this period, the methanol, ethyl acetate, $t$-butanol and aqueous extracts of the stems of Pereskia bleo were appropriately diluted (50 to $800 \mu \mathrm{g} / \mathrm{mL}$ ) in medium containing $0.8 \%$ (v/v) dimethyl sulphoxide (DMSO) (Sigma, France). Various concentrations (25 to 100 $\mu \mathrm{g} / \mathrm{mL}$ ) of cisplatin (positive control) were prepared in culture medium containing $0.8 \%(\mathrm{v} / \mathrm{v})$ DMSO. The diluted solutions were filtered through sterile $0.22 \mu \mathrm{m}$ filter units. The diluted solutions of Pereskia bleo stem extracts or cisplatin $(100 \mu \mathrm{L})$ were added to the wells (in triplicates) containing the $\mathrm{NIH} / 3 \mathrm{~T} 3$ or $4 \mathrm{~T} 1$ cells in the sterile $96-$ well plate. The final concentrations of the stem extracts in the assay ranged from 12.5 to $400 \mu \mathrm{g} / \mathrm{mL}$ while cisplatin ranged from 1.6 to $50 \mu \mathrm{g} / \mathrm{mL}$. The negative control in the assay was cells in culture medium containing $0.4 \%(\mathrm{v} / \mathrm{v})$ DMSO (the DMSO concentration was the same as that in the extract-treated wells, and no effect on the cells was observed at this DMSO concentration). The plates were incubated at $37^{\circ} \mathrm{C}$ in a humidified $\mathrm{CO}_{2}$ incubator for 24,48 and 72 hours.

After the designated period of incubation, MTT solution $(20 \mu \mathrm{L}, 5 \mathrm{mg} / \mathrm{mL}$ in PBS $)$ was added to each of the wells. The plate was further incubated at $37^{\circ} \mathrm{C}$ for 4 hours in a $5 \% \mathrm{CO}_{2}$ incubator. Following this, the supernatant in each well was removed carefully (the purple formazan product was attached to the bottom of the well). Dimethylsulphoxide $(50 \mu \mathrm{L})$ was then added to each well to dissolve the purple formazan product. The absorbance of the solution in each well was determined using an ELISA plate reader at the measurement wavelength of $570 \mathrm{~nm}$. The percentage cell viability in each well was calculated by the formula:

Percentage cell viability $=$

Absorbance at $570 \mathrm{~nm}$ of treated well $\times 100 \%$

Absorbance at $570 \mathrm{~nm}$ of negative control

\section{Statistical analysis}

The commercially available statistical analysis software (SPSS version 13.0) was used. The percentage viability of cells treated with each concentration of the Pereskia bleo extract or cisplatin with that of the negative control were compared. The 
p-value was set at 0.05 . A p-value of less than or equal to 0.05 was considered statistically significantly.

\section{ABTS radical cation scavenging activity of} Pereskia bleo stem extracts

The assay is based on the ability of substances with antioxidant properties to scavenge 2, 2'-azinobis-(3ethylbenzothiazoline-6-sulfonic acid) (ABTS) radical cations, which are blue-green in colour and absorb at $734 \mathrm{~nm}$ [6]. Any positive reaction will lead to the decolourisation of the ABTS radical cations. The methanol and aqueous extracts of the stems of Pereksia bleo was dissolved in $0.01 \mathrm{M}$ phosphate buffered saline (PBS) while the ethyl acetate and $t$ butanol extracts were dissolved in $0.8 \%$ (v/v) DMSO. Trolox and vitamin $\mathrm{C}$ were used as positive controls in this assay. To perform this assay, the ABTS solution $(715 \mu \mathrm{L}, 5 \mathrm{mM})$ was mixed with potassium persulfate solution $(285 \mu \mathrm{L}, 2.5 \mathrm{mM})$ and the reaction mixture was kept in the dark at room temperature for 12 - 16 hours for the generation of ABTS radical cations. The ABTS radical cation solution was appropriately diluted with $0.01 \mathrm{M}$ PBS to give an absorbance of $0.7 \pm 0.2$ at $734 \mathrm{~nm}$. To $990 \mu \mathrm{L}$ of this diluted ABTS radical cation solution, $10 \mu \mathrm{L}$ of each of the concentrations of the Pereskia bleo stem extracts, Trolox or vitamin $\mathrm{C}$ was added. The absorbance of the mixture at $734 \mathrm{~nm}$ was recorded at every minute for a period of 12 minutes. The experiment was repeated five times for each concentration of the extracts, Trolox or vitamin C. The percentage inhibition of ABTS radical cation at each time point was calculated using the formula:

Percentage inhibition $=$

Initial Absorbance-Absorbance at time of interest $\times 100 \%$

Initial Absorbance

\section{Cell death detection by enzyme-linked immunosorbent assay (ELISA)}

The NIH/3T3 cells were diluted in culture medium to a concentration of $1 \times 10^{5}$ cells $/ \mathrm{mL}$. This diluted cell suspension $(50 \mu \mathrm{L})$ was added to the wells of a sterile 96-well flat-bottom tissue culture plate. The plate was left in a humidified $5 \% \mathrm{CO}_{2}$ incubator at $37^{\circ} \mathrm{C}$ for 2 hours. The extracts from the stems of Pereksia bleo (methanol, ethyl acetate, $t$-butanol and aqueous extracts) were dissolved in DMSO and diluted with the culture medium to a concentration of 100 and $200 \mu \mathrm{g} / \mathrm{mL}$. The concentration of DMSO in the diluted solutions was $0.8 \%(\mathrm{v} / \mathrm{v})$. These solutions were filtered through a sterile $0.22 \mu \mathrm{m}$ filter unit. A $50 \mu \mathrm{L}$ aliquot of the diluted solution (200 or $100 \mu \mathrm{g} / \mathrm{mL}$ ) of the Pereskia bleo stem extracts, Trolox or vitamin $\mathrm{C}$ was then added (in triplicates) to the respective wells in the plate containing NIH/3T3 cells at the concentration of $5 \times 10^{3}$ cells-per-well. To test for the ability of these extracts to protect NIH/3T3 cells against DPPH (2,2-diphenyl-1Picrylhydrazyl) induced cell death, $50 \mu \mathrm{L}$ of $30 \mu \mathrm{M}$ DPPH solution was added to the relevant wells one hour after the NIH/3T3 cells were incubated in the presence of the appropriately diluted extracts, Trolox, Vitamin $\mathrm{C}$ or cultured medium. The plate was incubated at $37^{\circ} \mathrm{C}$ for 24 hours. Trolox and vitamin $\mathrm{C}$ were used as the positive controls while medium containing $0.4 \%(\mathrm{v} / \mathrm{v})$ DMSO served as the negative control.

Cell death due to apoptosis was performed using the Cell Death Detection ELISA ${ }^{\text {PLUS }}$ kit according to the manufacturer's instruction (Roche Applied Science, Germany). This assay is based on a quantitative sandwich-enzyme-immunoassay principle that utilises mouse monoclonal antibodies directed against DNA and histones associated DNA fragments. Briefly, the plate was centrifuged at $200 \mathrm{~g}$ for 10 minutes at room temperature after 24 hours. The supernatant was completely removed. Then, the pellet in each well was resuspended in $200 \mu \mathrm{L}$ of lysis buffer (provided by manufacturer) and the plate was incubated at room temperature for 30 minutes. Following this, the plate was centrifuged at $200 \times \mathrm{g}$ for 5 minutes. An aliquot of $20 \mu \mathrm{L}$ of the supernatant containing the cytoplasmic fraction in each well was carefully transferred into appropriate wells of a streptavidin-coated plate (provided by manufacturer) for further analysis. Then, $80 \mu \mathrm{L}$ of an immunoreagent (provided by manufacturer) was added into each well. The plate was covered with an adhesive foil and gently shaken at $200 \mathrm{rpm}$ for two hours. The solution in each well was then removed and the wells were thoroughly rinsed thrice with 300 $\mu \mathrm{L}$ of incubation buffer (provided by manufacturer). Following this, $100 \mu \mathrm{L}$ of ABTS solution (provided by manufacturer) was added into each well and the plate was gently shaken at $200 \mathrm{rpm}$ until suitable colour development was obtained (20-30 minutes). The absorbance of each well was determined using an ELISA plate reader at $405 \mathrm{~nm}$ with a reference wavelength of $490 \mathrm{~nm}$. The enrichment factor was calculated using the following formula provided by the manufacturer.

Enrichment factor $=$

Absorbance at $405 \mathrm{~nm}$ of treated cells

Absorbance at $405 \mathrm{~nm}$ of untreated cells

\section{RESULTS}

\section{Cell proliferation assay}

The $4 \mathrm{~T} 1$ or NIH/3T3 cells were cultured in the presence and absence of various concentrations (12.5 
to $400 \mu \mathrm{g} / \mathrm{mL}$ ) of the stem extracts of Pereskia bleo. Proliferation is expressed as a percentage of viable cells compared to untreated cells. Cisplatin was used as the positive control in the assay. A gradual decrease in cell viability with increasing extract concentration was observed for all the stem extracts in both 4T1 (see Figure 1) and NIH/3T3 cells (see Figure 2). However, the reduction of cell viability observed for both cell lines was not statistically significant $(p>0.05)$ even when these cells were treated with up to $400 \mu \mathrm{g} / \mathrm{mL}$ of the stem extracts for 24 hours. However, after 48 hours of co-culturing with $400 \mu \mathrm{g} / \mathrm{mL}$ of the aqueous stem extract, a significant $(\mathrm{p}<0.05)$ reduction in cell viability was observed in 4T1 cells (see Figure 1). In the NIH/3T3 cells, a significant $(\mathrm{p}<0.05)$ reduction in cell viability was observed when these cells were cultured with 200 and $400 \mu \mathrm{g} / \mathrm{mL}$ of the ethyl acetate extract as well as $400 \mu \mathrm{g} / \mathrm{mL}$ of the aqueous extract for 48 hours (see Figure 2). There was also inhibition of proliferation when these cells were cultured with 400 $\mu \mathrm{g} / \mathrm{mL}$ of the ethyl acetate stem extract and $200 \mu \mathrm{g} / \mathrm{mL}$ of the $t$-butanol stem extract for 72 hours (see Figure 2). The $\mathrm{IC}_{50}$ values for all the extracts were greater than the $400 \mu \mathrm{g} / \mathrm{mL}$ in both cell lines. The cell proliferation assays could not be carried out at extract concentrations greater than $400 \mu \mathrm{g} / \mathrm{mL}$ due to constraints associated with extract insolubility. There was decreased proliferation of the NIH/3T3 cells compared to the $4 \mathrm{~T} 1$ cells when these cells were co-cultured with $400 \mu \mathrm{g} / \mathrm{mL}$ of the extracts, in particular, the ethyl acetate extract, for 72 hours (see Table 1). A significant ( $p<0.05$ ) enhancement of cell growth was observed in 4T1 cells co-cultured with 12.5 to $400 \mu \mathrm{g} / \mathrm{mL}$ of methanol extract, 12.5 to $25 \mu \mathrm{g} / \mathrm{mL}$ of ethyl acetate extract, 12.5 to $100 \mu \mathrm{g} / \mathrm{mL}$ of $t$-butanol extract and 12.5 to $50 \mu \mathrm{g} / \mathrm{mL}$ of aqueous extract for 24 hours. Similar growth enhancement was observed when these cells were co-cultured with $12.5 \mu \mathrm{g} / \mathrm{mL}$ of ethyl acetate stem extract, 12.5 and 25 $\mu \mathrm{g} / \mathrm{mL}$ of $t$-butanol extract for 48 hours and 12.5 $\mu \mathrm{g} / \mathrm{mL}$ of methanol extract for 72 hours. There was also a significant $(\mathrm{p}<0.05)$ enhancement of cell growth in the NIH/3T3 cells co-cultured with 12.5 $\mu \mathrm{g} / \mathrm{mL}$ of ethyl acetate extract for 72 hours.

Co-culturing of the 4T1 cells with cisplatin (1.56 to $50 \mu \mathrm{g} / \mathrm{mL}$ ) for 24,48 and 72 hours led to a significant $(\mathrm{p}<0.05)$ reduction of cell survival. The $\mathrm{IC}_{50}$ values for cisplatin against the 4T1 cells were found to be $19.7 \mu \mathrm{g} / \mathrm{mL}, 1.8 \mu \mathrm{g} / \mathrm{mL}$ or $2.1 \mu \mathrm{g} / \mathrm{mL}$ when these cells were cultured in the presence of cisplatin for 24,48 or 72 hours, respectively. A statistically significant $(\mathrm{p}<0.05)$ reduction in cell viability was also observed when NIH/3T3cells were cultured with cisplatin $(1.56 \mu \mathrm{g} / \mathrm{mL}$ to $50 \mu \mathrm{g} / \mathrm{mL})$ for 48 and 72 hours. The $\mathrm{IC}_{50}$ values for cisplatin against the NIH/3T3cells were found to be $24.1 \mu \mathrm{g} / \mathrm{mL}, 2.0 \mu \mathrm{g} / \mathrm{mL}$ and $2.7 \mu \mathrm{g} / \mathrm{mL}$ at 24,48 and 72 hours, respectively.

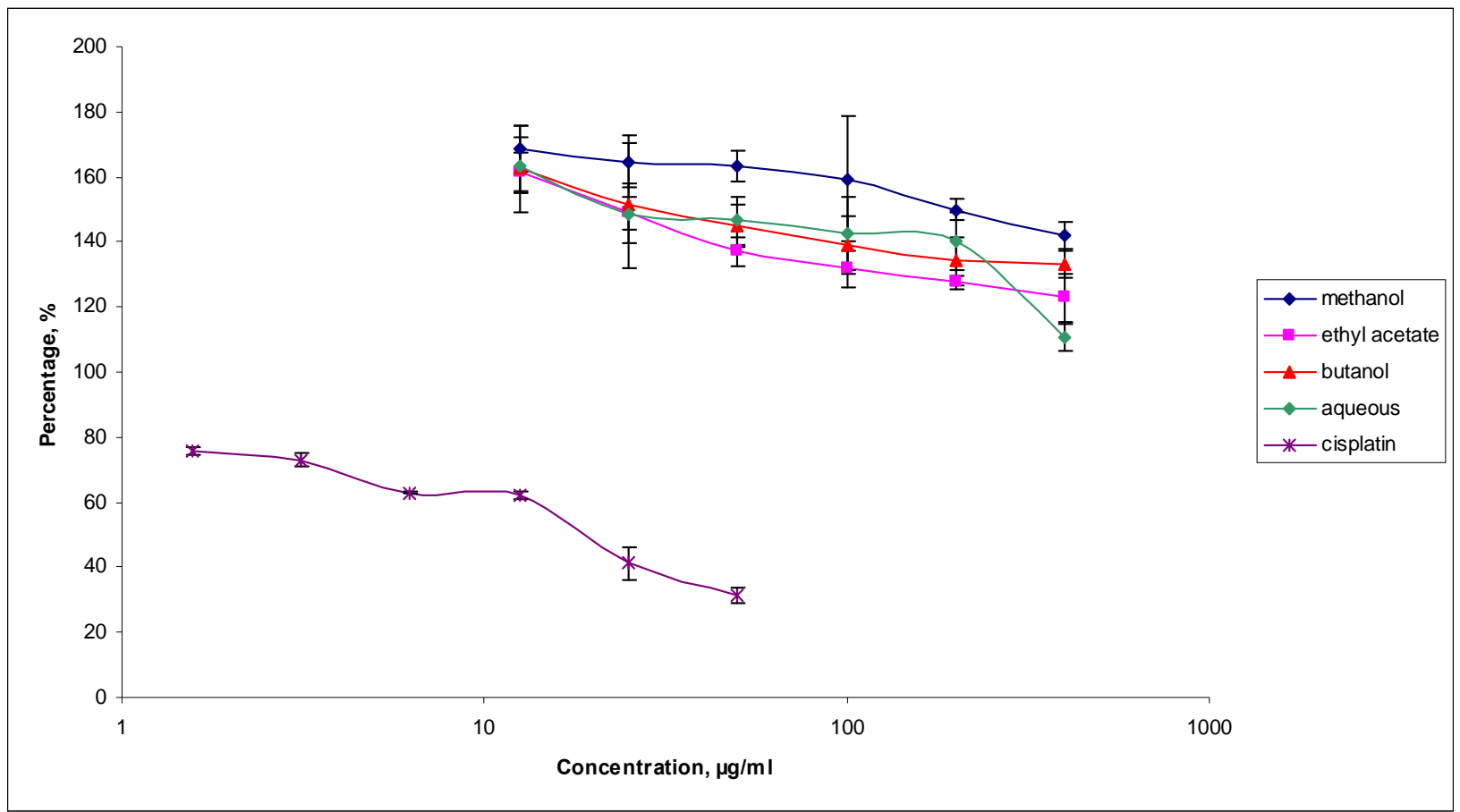

Figure 1a. Percentage cell viability of 4T1 cells cultured in the presence of methanol, ethyl acetate, $t$-butanol and aqueous extracts of the stems of Pereskia bleo and cisplatin for 24 hours. 


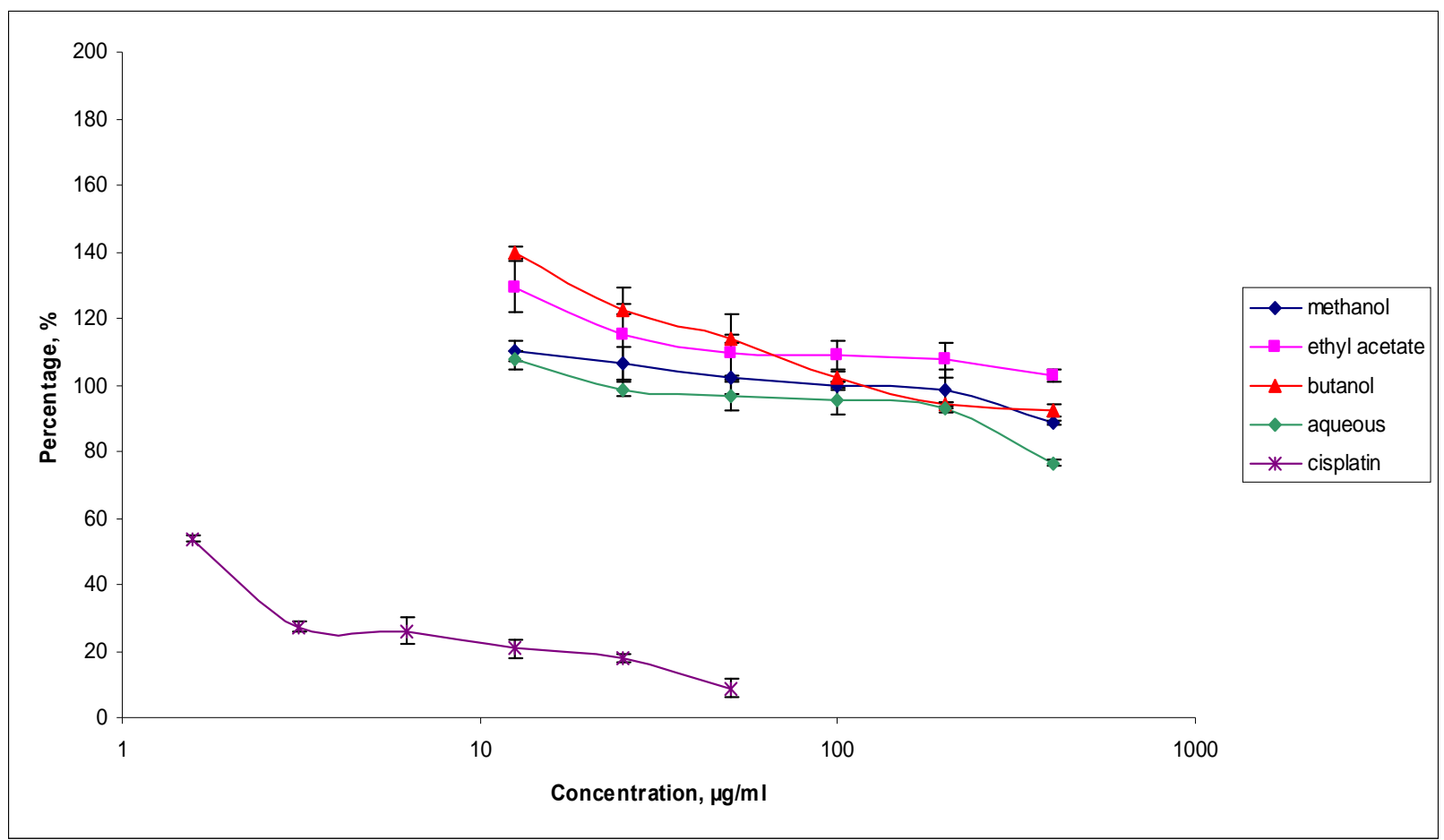

Figure 1b. Percentage cell viability of $4 \mathrm{~T} 1$ cells cultured in the presence of methanol, ethyl acetate, $t$-butanol and aqueous extracts of the stems of Pereskia bleo and cisplatin for 48 hours.

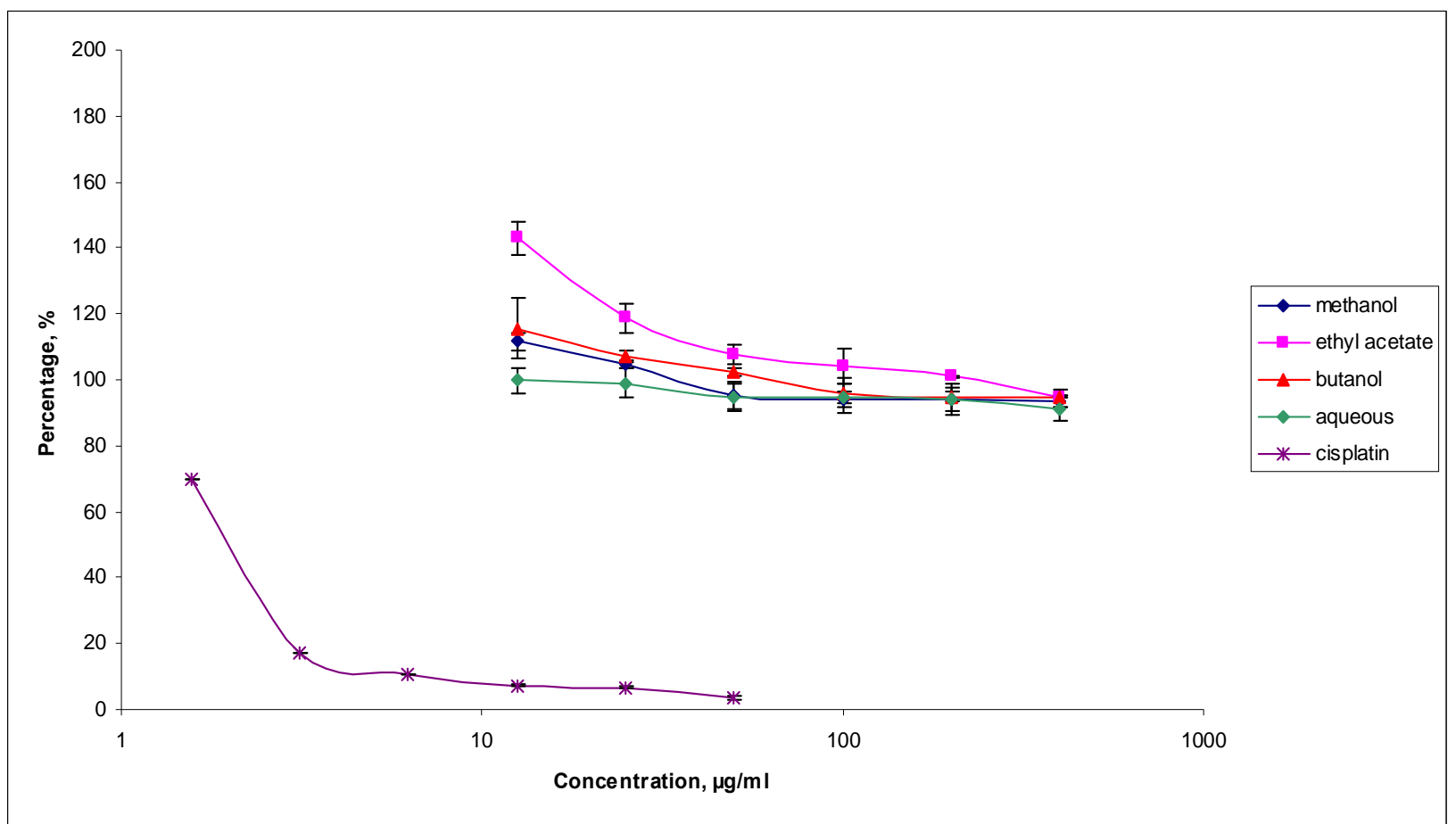

Figure 1c. Percentage cell viability of $4 \mathrm{~T} 1$ cells cultured in the presence of methanol, ethyl acetate, $t$-butanol and aqueous extracts of the stems of Pereskia bleo and cisplatin for 72 hours. 


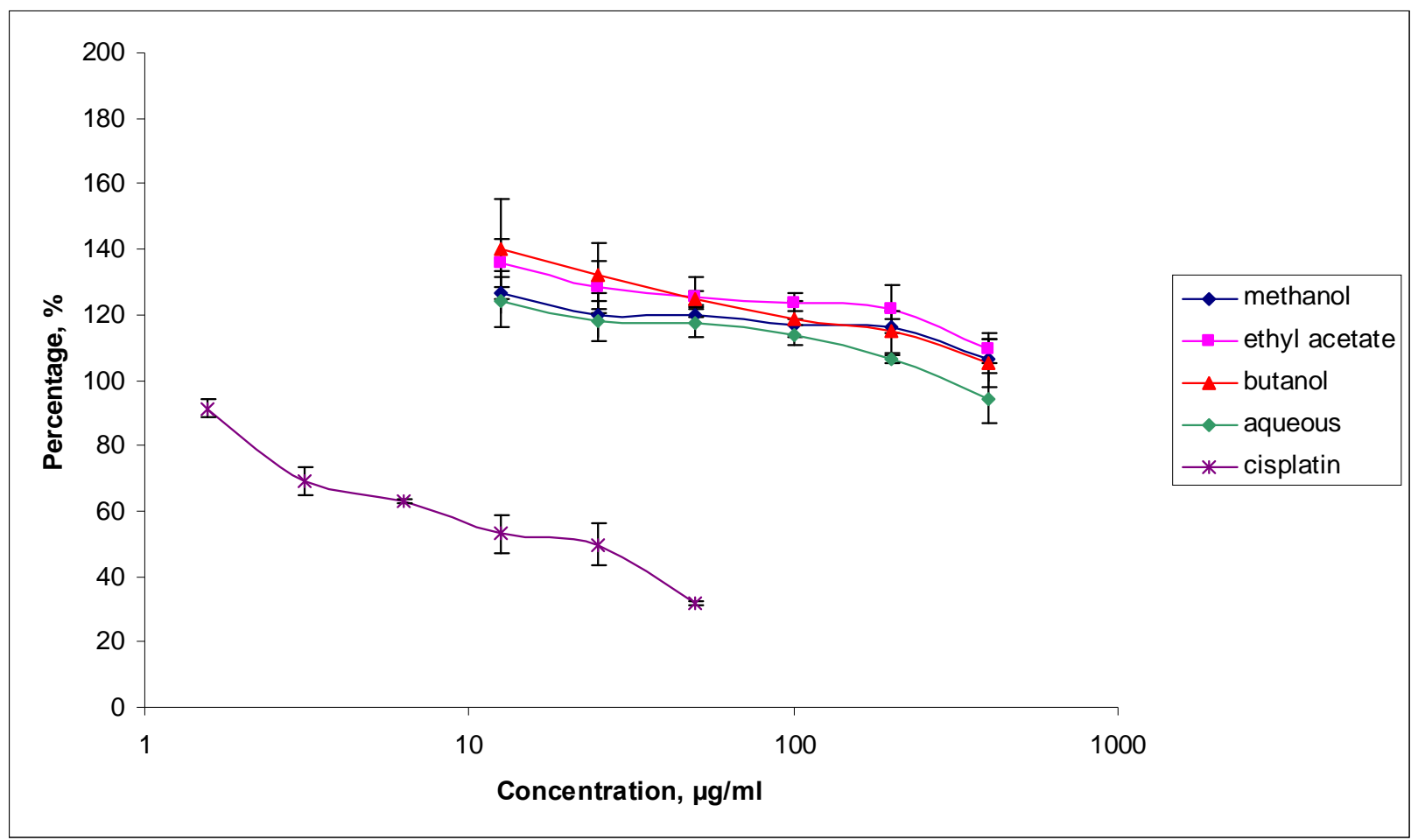

Figure 2a. Percentage cell viability of NIH/3T3 cells cultured in the presence of methanol, ethyl acetate, $t$-butanol and aqueous extracts of the stems of Pereskia bleo and cisplatin for 24 hours.

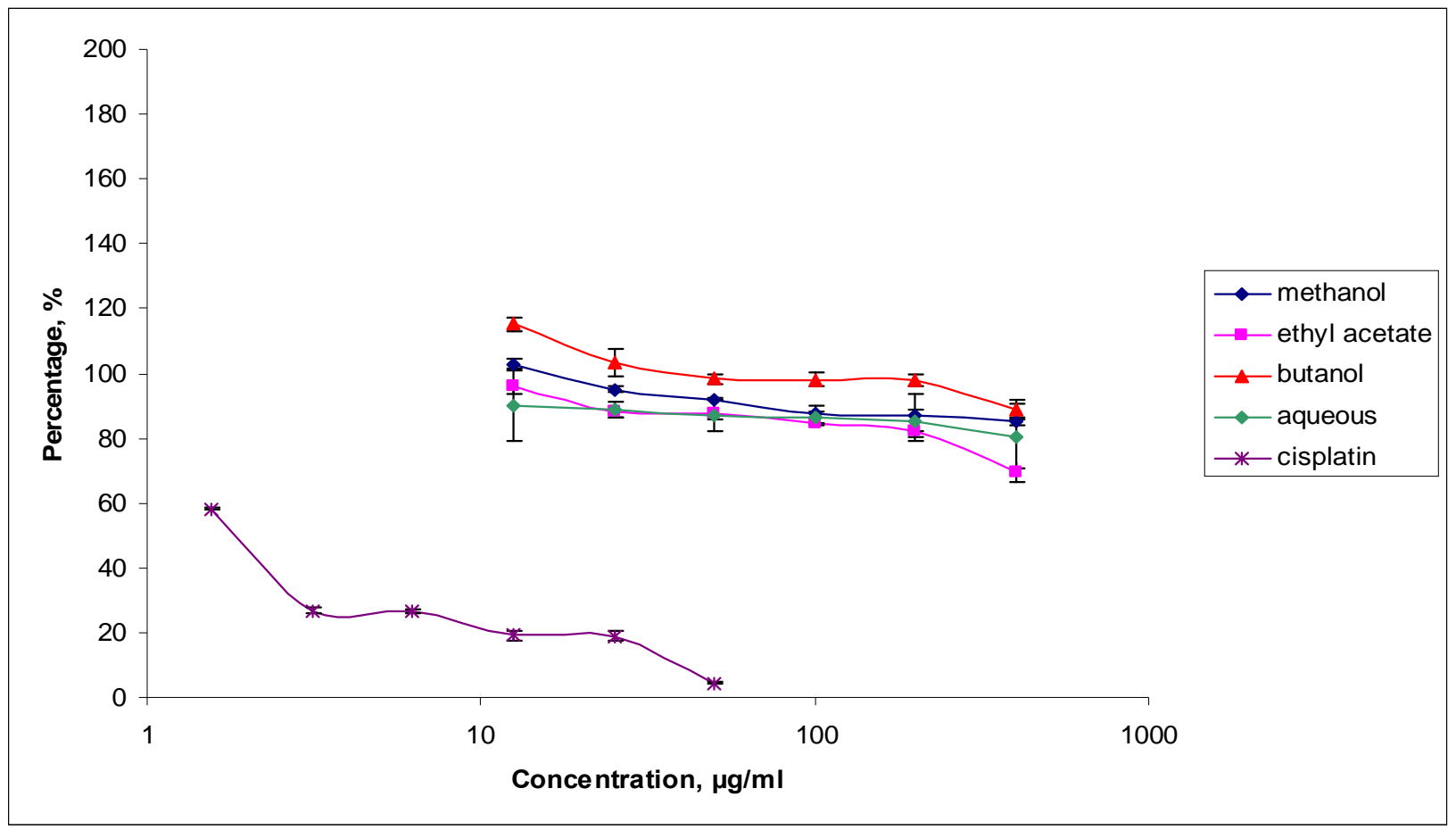

Figure 2b. Percentage cell viability of NIH/3T3 cells cultured in the presence of methanol, ethyl acetate, $t$-butanol and aqueous extracts of the stems of Pereskia bleo and cisplatin for 48 hours 


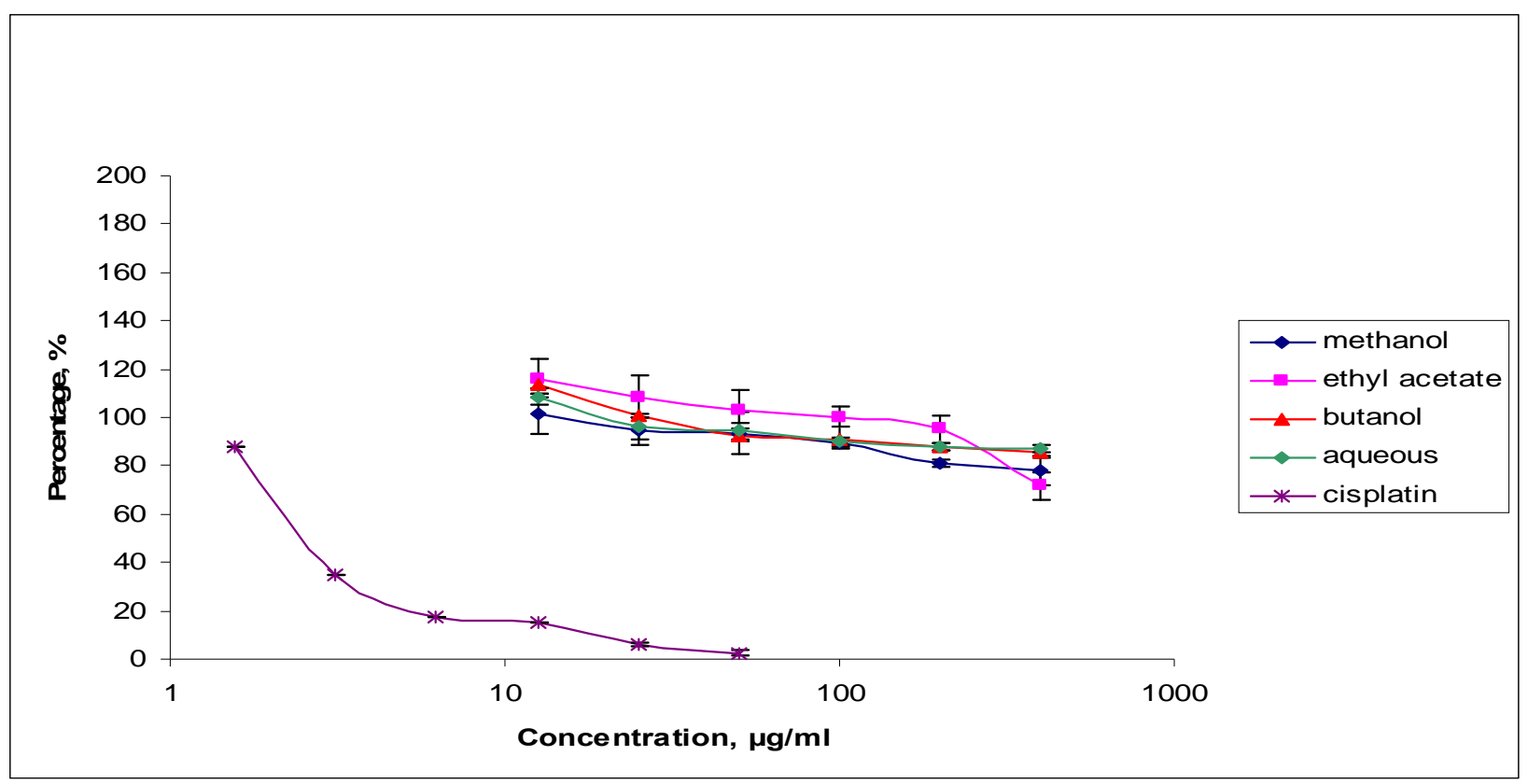

Figure 2c. Percentage cell viability of NIH/3T3 cells cultured in the presence of methanol, ethyl acetate, $t$-butanol and aqueous extracts of the stems of Pereskia bleo and cisplatin for 72 hours.

Table 1. The percentage of viable $4 \mathrm{~T} 1$ and NIH/3T3 cells treated with $400 \mu \mathrm{g} / \mathrm{mL}$ of extracts from the stem of Pereskia bleo for 72 hours.

\begin{tabular}{llc}
\hline Pereskia bleo stem extracts & \multicolumn{2}{l}{ Percentage Viable Cells $( \pm$ S.D.) } \\
& 4T1 cells & NIH/3T3 cells \\
\hline Methanol extract & $93.53 \pm 1.72$ & $77.71 \pm 5.61$ \\
Ethyl acetate extract & $94.39 \pm 2.52$ & $71.86 \pm 5.59$ \\
$t$-Butanol extract & $94.80 \pm 0.23$ & $85.60 \pm 1.60$ \\
Aqueous stem extract & $90.96 \pm 3.64$ & $87.12 \pm 1.67$ \\
\hline
\end{tabular}

ABTS radical cation scavenging activity of Pereskia bleo stem extracts

The final concentrations of the methanol, ethyl acetate and aqueous extracts used in these experiments were between 5 and $100 \mu \mathrm{g} / \mathrm{mL}$, while the final concentrations of the $t$-butanol extract used in the experiments were between 2.5 and $50 \mu \mathrm{g} / \mathrm{mL}$ due to constraints associated with insolubility. The final concentrations of the positive controls, Trolox and vitamin $\mathrm{C}$ ranged between 2.5 to $25 \mu \mathrm{M}$. In addition to being a positive control, Trolox also served as a standard for calculating the Trolox Equivalent (TE) per gram values of the dry extract, which is a measurement generally used for expressing the antioxidant capacity of plant extracts. In this assay, the ABTS radical cations absorb strongly at $734 \mathrm{~nm}$ and substances with ABTS radical cation scavenging ability will cause the decolourisation of the ABTS radical cations. This would result in a reduction of absorbance at $734 \mathrm{~nm}$. Figure 3 shows the percentage inhibition of the
ABTS radical cations over a period of 12 mins for each extract. As shown in Figure 3, the percentage inhibition of the ABTS radical cations is proportional to the concentrations of the stem extracts and positive controls. The stem extracts and positive controls exhibited the highest rate of ABTS radical cation scavenging activity in the first minute. For the positive controls, Trolox and vitamin $\mathrm{C}$, the percentage inhibition of ABTS radical cation reached the maximum extent by the first minute. On the other hand, the radical scavenging activity of the stem extracts stabilised after six minutes for all the stem extracts (see Figure 3). The reactions were not monitored for more than 12 minutes as the ABTS radical cations have been reported to be instable and would undergo self-degradation if left for a longer period [6]. Taking into consideration of the above factors, the values of the percentage inhibition of ABTS radical cations for the stem extracts and positive controls at the sixth minute were chosen for the subsequent calculation of the Trolox Equivalent 
(TE) per gram dry extract. The graphs of the percentage inhibition of ABTS radical cations at the sixth minute versus concentration for the stem extracts, Trolox and vitamin $\mathrm{C}$ are shown in Figure 4. The linear regression equations for the graphs of the stem extracts, Trolox and vitamin $\mathrm{C}$ are shown in the corresponding figures. Among the stem extracts, the $t$-butanol extract exhibited the highest ABTS radical cation scavenging activity with Trolox Equivalent values of $450 \mu$ mole TE/g dry weight, followed by the ethyl acetate extract $(213 \mu$ mole TE/g dry weight), methanol extract (117 $\mu$ mole TE/g dry weight) and aqueous extract $(70 \mu$ mole TE/g dry weight). However, the Trolox Equivalent values of these extracts are much less than that of vitamin $\mathrm{C}$, i.e. $5158 \mu$ mole $\mathrm{TE} / \mathrm{g}$, which is equivalent to a Trolox Equivalent Antioxidant Capacity (TEAC) value of 0.9 (literature value 1.05) [6].

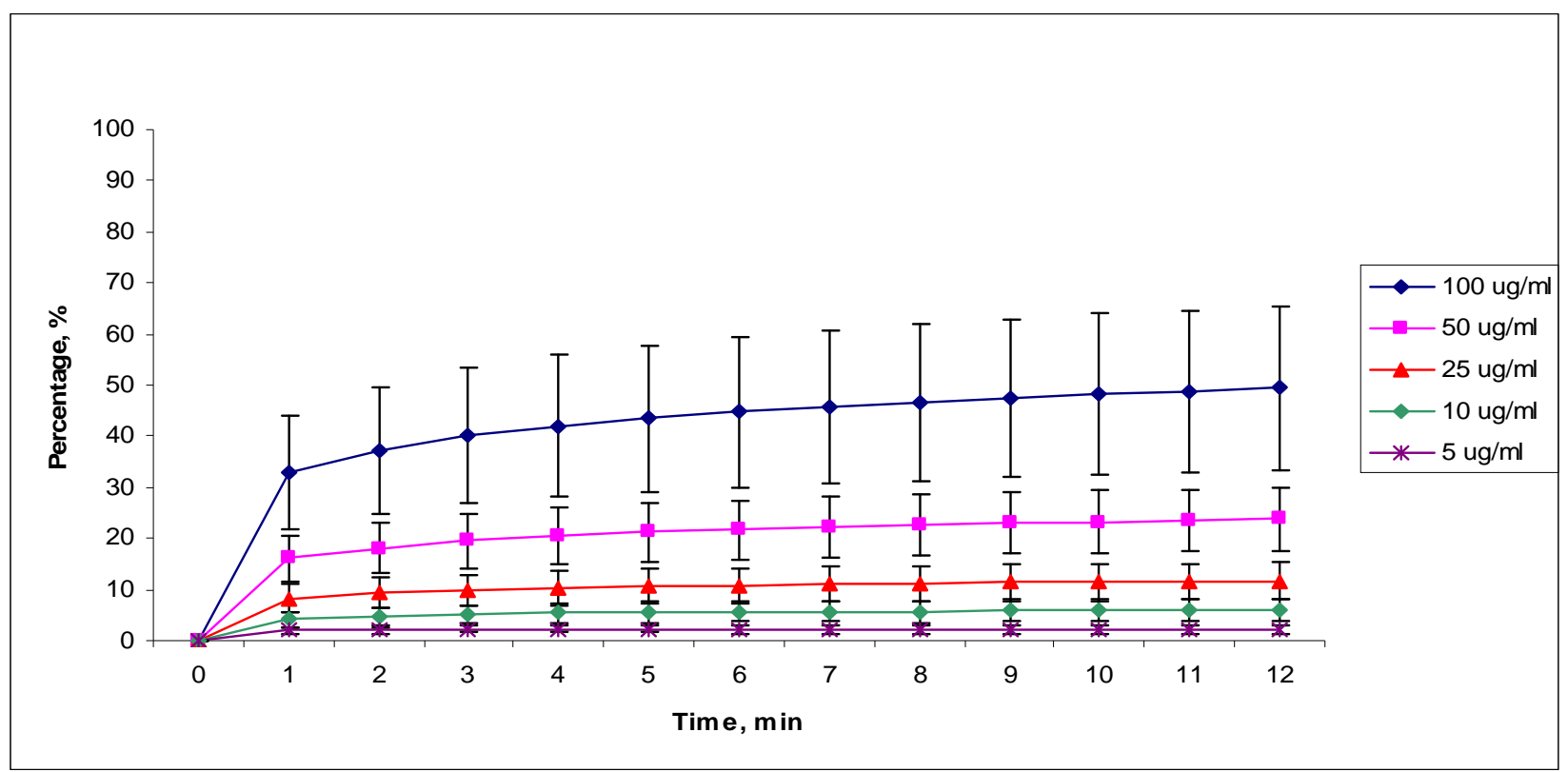

Figure 3a. Percentage inhibition of ABTS radical cations in the presence of various concentrations methanol over 12 minutes.

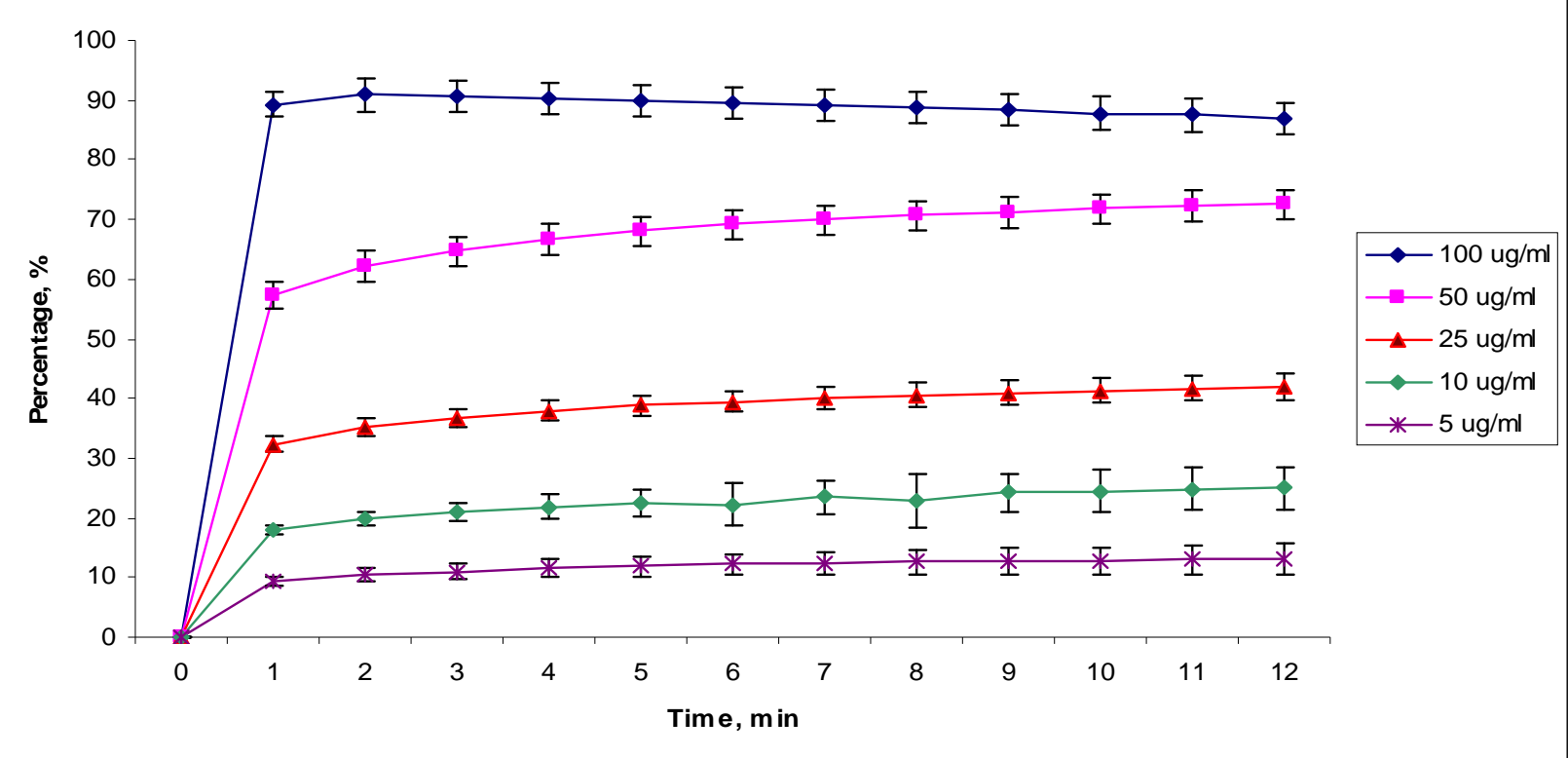

Figure 3b. Percentage inhibition of ABTS radical cations in the presence of various concentrations of ethyl acetate over 12 minutes. 


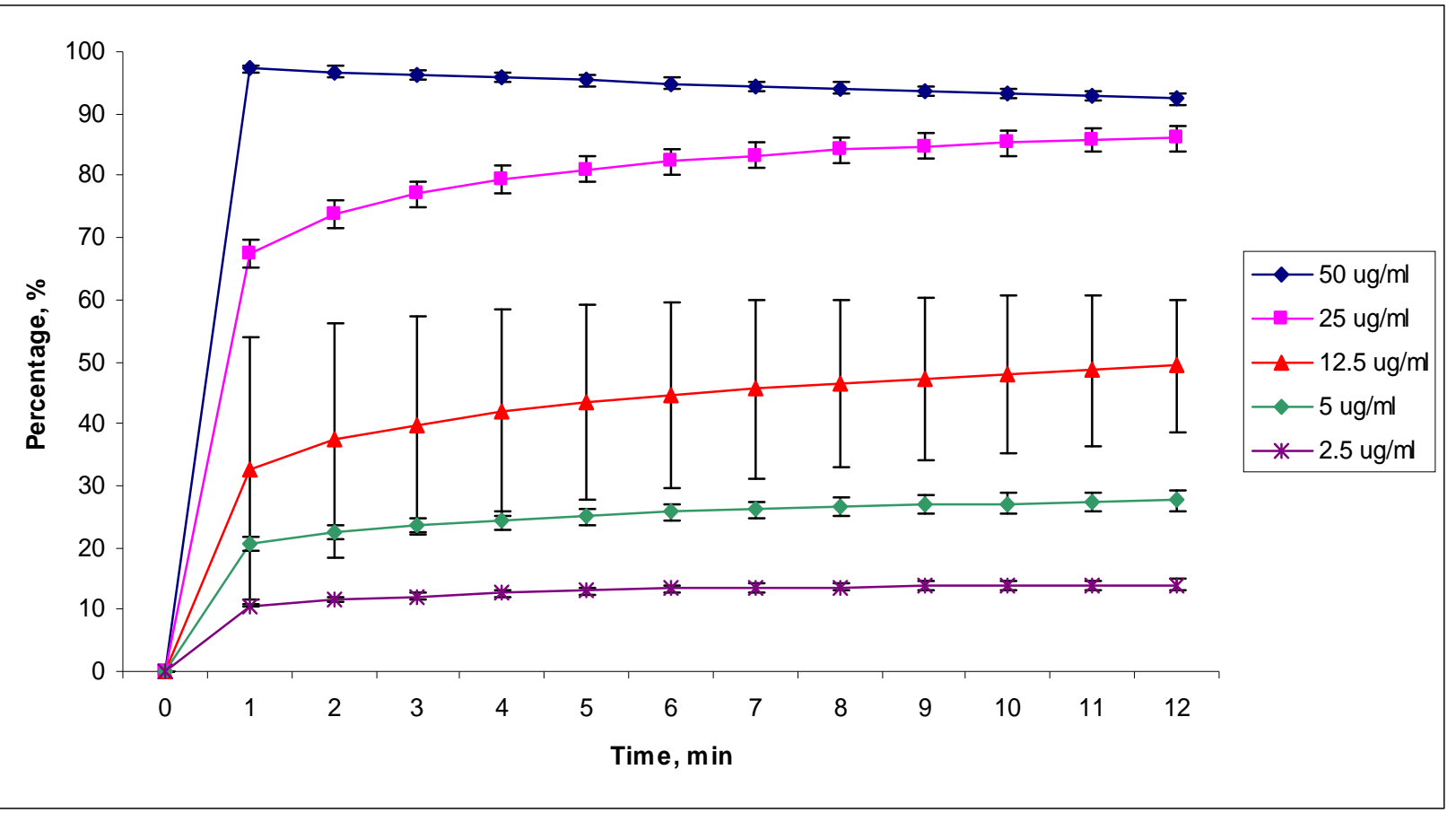

Figure 3c. Percentage inhibition of ABTS radical cations in the presence of various concentrations of $t$-butanol and over 12 minutes.

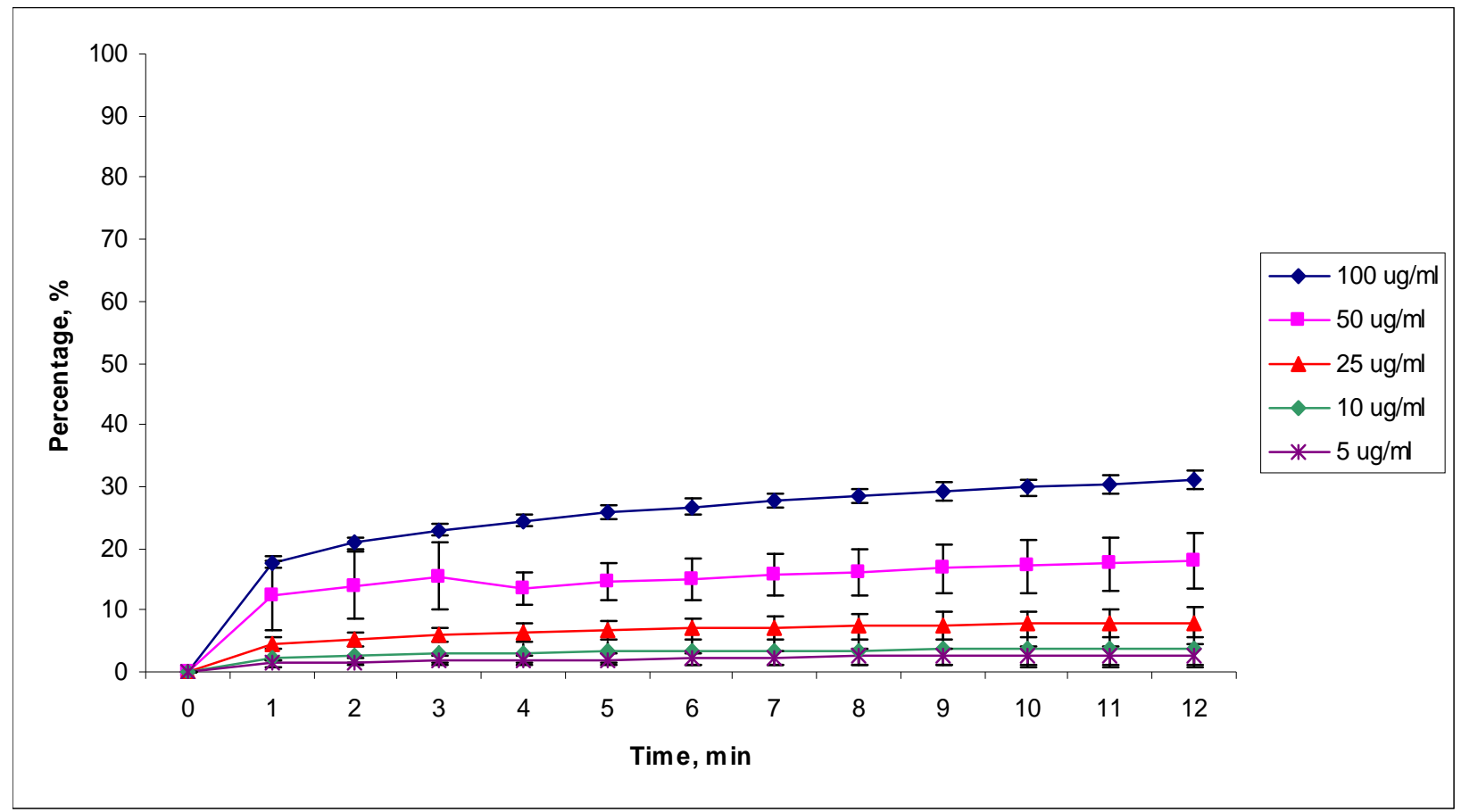

Figure 3d. Percentage inhibition of ABTS radical cations in the presence of various concentrations of aqueous extracts from stem of Pereskia bleo over 12 minutes. 


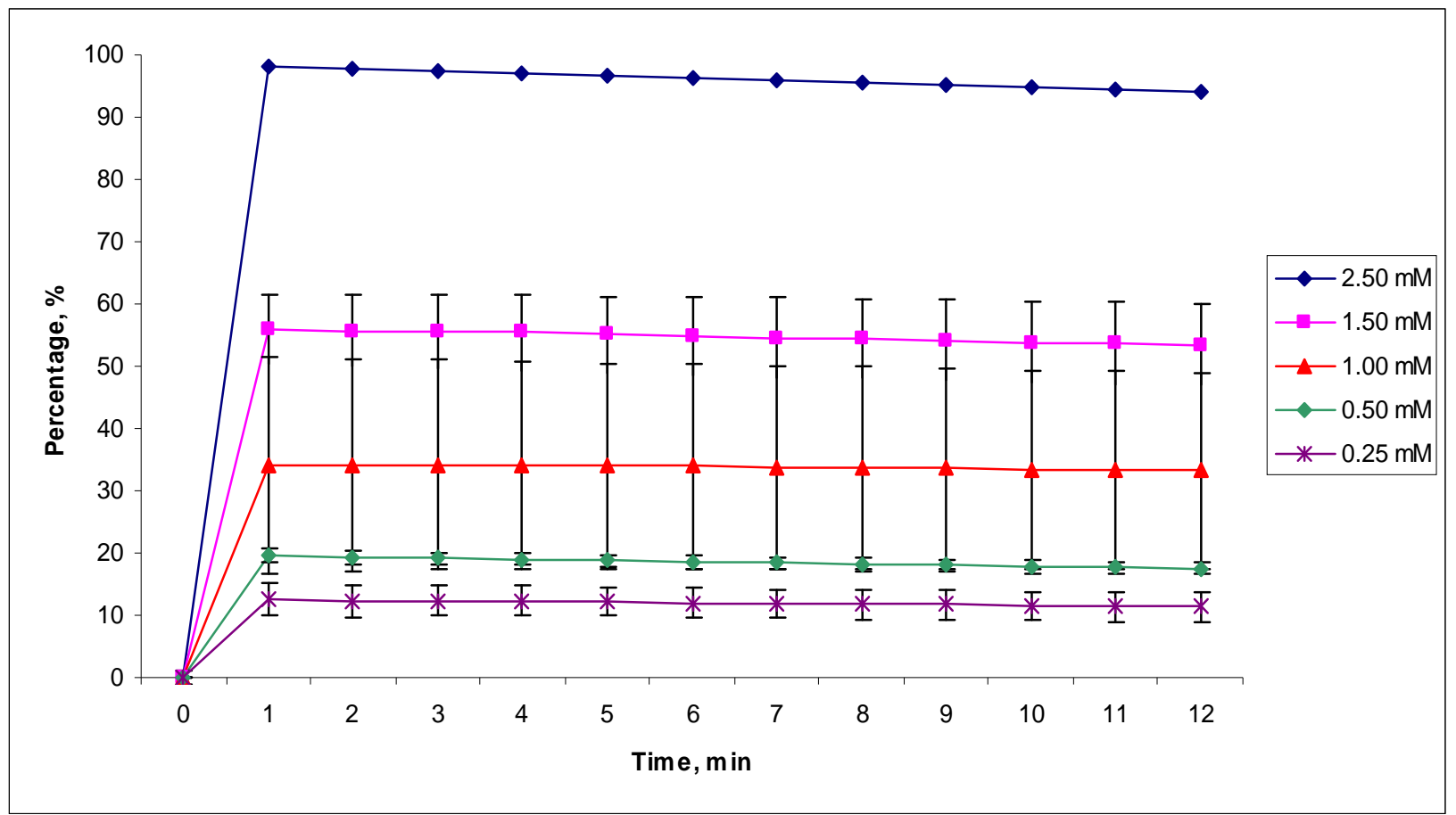

Figure 3e. Percentage inhibition of ABTS radical cations in the presence of various concentrations of Trolox over 12 minutes.

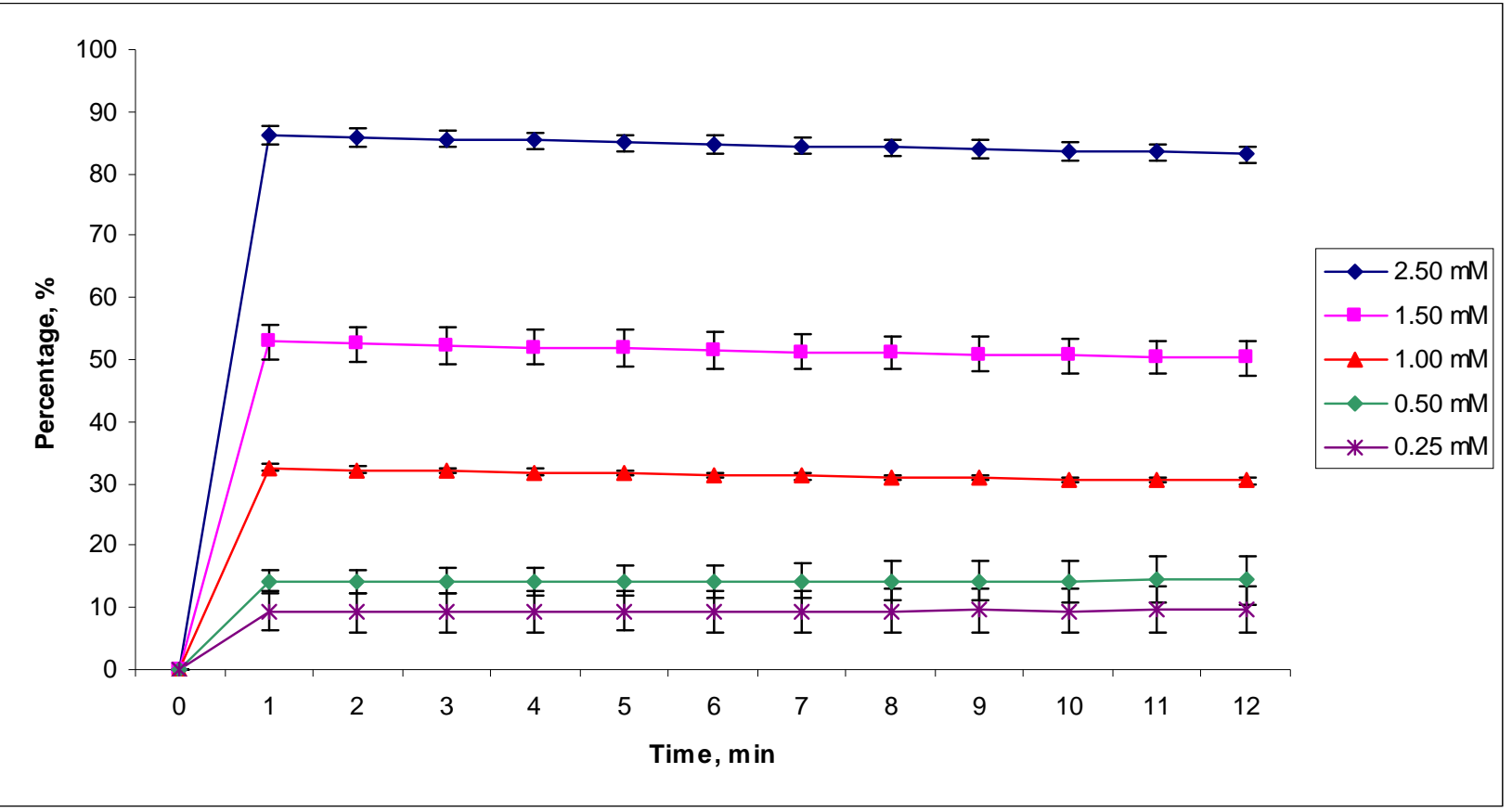

Figure 3f. Percentage inhibition of ABTS radical cations in the presence of various concentrations of Vitamin C over 12 minutes. 


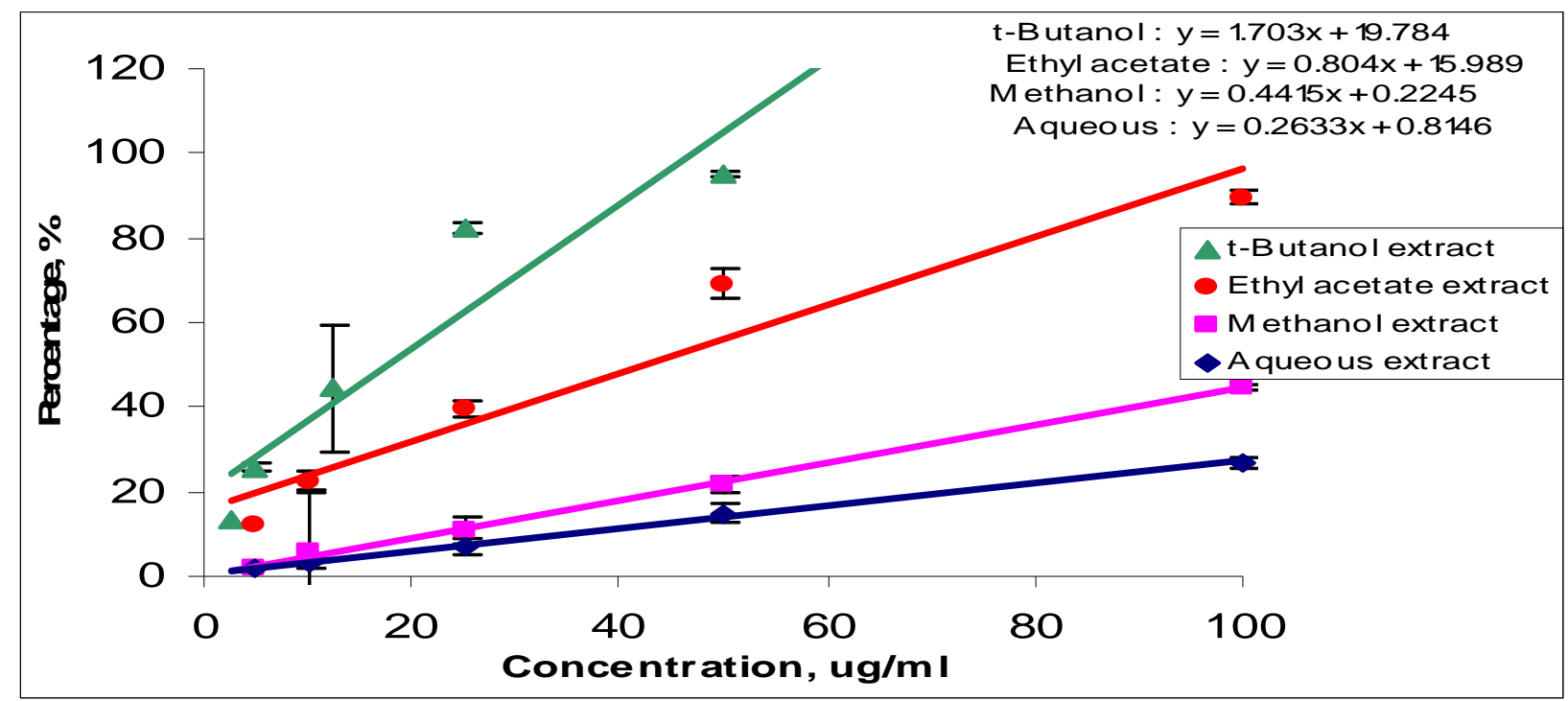

(a) Stem extracts

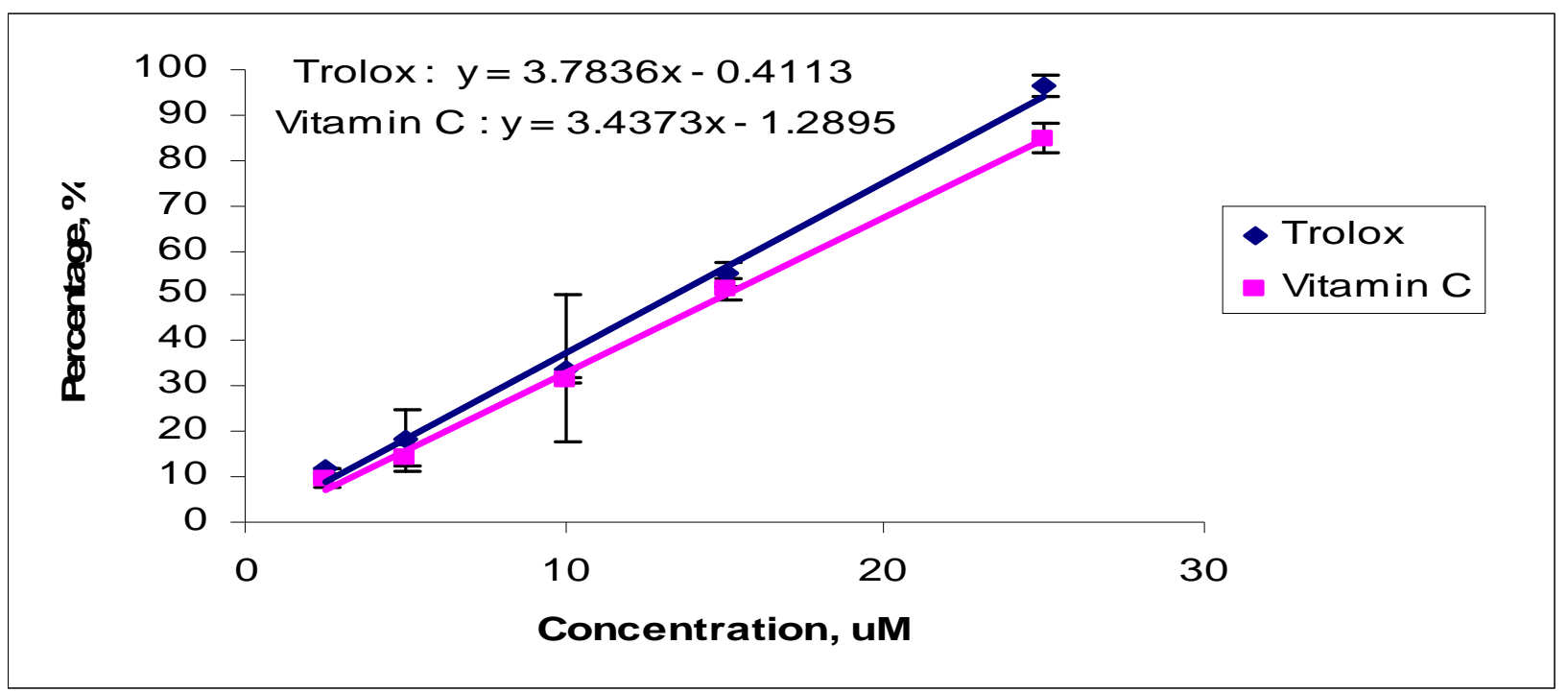

(b) Trolox and Vitamin C

Figure 4. Percentage inhibition of ABTS radical cations by various concentrations of the (a) extracts from the stems of Pereskia bleo, (b) Trolox and vitamin $\mathrm{C}$, at the sixth minutes of the assay.

Cell death detection by enzyme-linked immunosorbent assay (ELISA)

Ability of Pereskia bleo stem extracts to limit natural apoptotic cell death in NIH/3T3 cells.

Figure 5(a) shows the enrichment factors calculated when NIH/3T3 cells were cultured in the presence and absence of $50 \mu \mathrm{g} / \mathrm{mL}$ or $100 \mu \mathrm{g} / \mathrm{mL}$ extracts from the stems of Pereskia bleo. All the stem extracts of Pereskia bleo were able to reduce natural apoptotic cell death in NIH/3T3 cells, as indicated by an enrichment factor of less than one. The ability to limit natural apoptotic cell death in NIH/3T3 cells was greater at $50 \mu \mathrm{g} / \mathrm{mL}$ than at $100 \mu \mathrm{g} / \mathrm{mL}$ for all extracts. At the concentrations of $50 \mu \mathrm{g} / \mathrm{mL}$ and 100 $\mu \mathrm{g} / \mathrm{mL}$, the ethyl acetate extract showed the strongest ability to limit natural cell death by apoptosis in $\mathrm{NIH} / 3 \mathrm{~T} 3$ cells, the extent of which was greater than those of Trolox and vitamin $\mathrm{C}$.

Ability of Pereskia bleo stem extracts to limit oxidant-induced apoptotic cell death in NIH/3T3 cells.

The oxidant used in this study was $10 \mu \mathrm{M} 2$, 2diphenyl-1-picrylhydrazyl (DPPH). This concentration of DPPH had previously been determined to result in about $30-40 \%$ cell death in $\mathrm{NIH} / 3 \mathrm{~T} 3$ cells. The extent of cell death was analysed using a commercially available cell death detection 
ELISA kit. An increase in apoptotic cell death was observed in the NIH/3T3 cells cultured for 24 hours in the presence of $10 \mu \mathrm{M}$ DPPH. However, the extent of the DPPH-induced apoptotic cell death was reduced when the cells were pre-incubated with extracts from the stems of Pereskia bleo for one hour before DPPH were added to the culture wells (see
Figure 5(b)). The level of oxidant-induced apoptotic cell death was not significantly different in the presence of 50 or $100 \mu \mathrm{g} / \mathrm{mL}$ of the stem extracts. The protective effects of all the extracts against oxidant-induced cell death were greater than Trolox or vitamin $\mathrm{C}$.

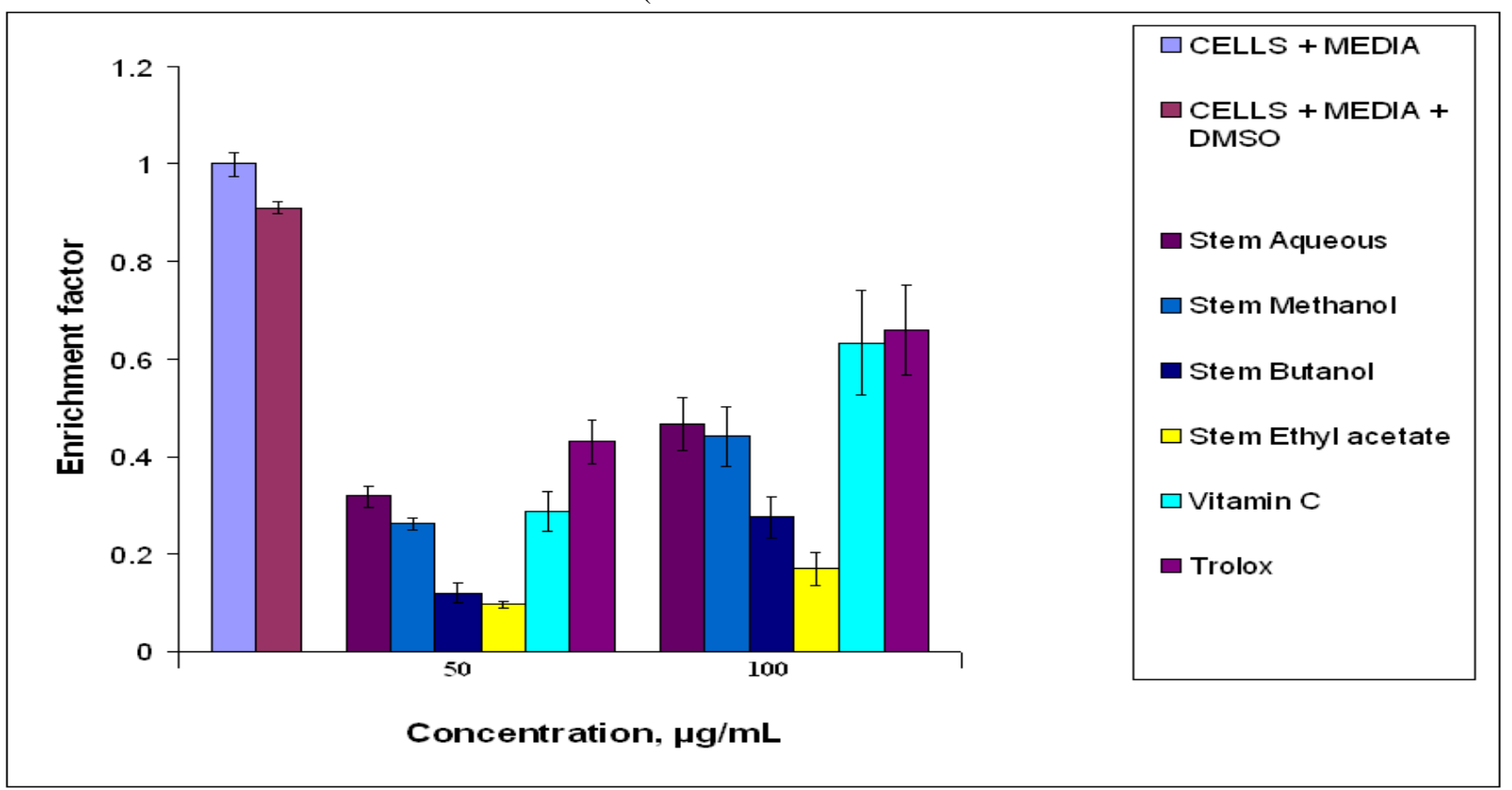

(a) Natural apoptotic death

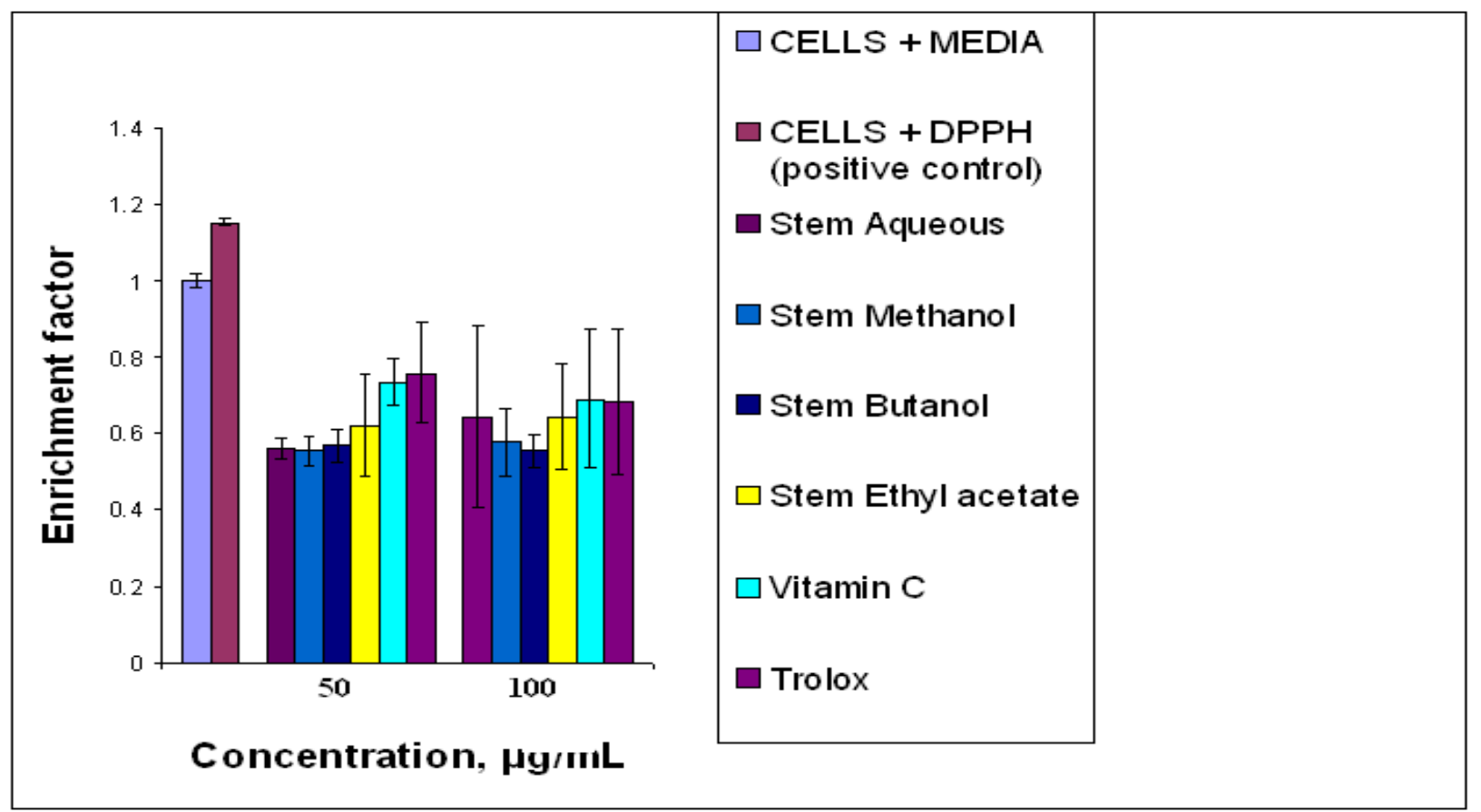

b) DPPH-induced apoptotic death

Figure 5. Comparison of the ability of extracts from the stems of Pereskia bleo to limit (a) natural apoptotic death, (b) DPPH-induced apoptotic death in NIH/3T3 cells. 


\section{DISCUSSIONS}

In this study, the anti-proliferative effects of the methanol, ethyl acetate, $t$-butanol and aqueous extracts of the stems of Pereskia bleo were evaluated on mouse mammary cancer cells (4T1) and normal mouse fibroblast cells (NIH/3T3) in culture media containing $10 \%$ foetal bovine serum. The $\mathrm{IC}_{50}$ values for all the crude and fractionated extracts of the stems of Pereskia bleo against both cell lines were greater than $400 \mu \mathrm{g} / \mathrm{mL}$. According to the US National Cancer Institute guideline, the crude extract of a plant should have an $\mathrm{IC}_{50}$ value of less than $20 \mu \mathrm{g} / \mathrm{mL}$ for it to be considered cytotoxic against the treated cells [7]. The results suggested that these extracts did not possess significant amount of compounds with antiproliferative properties. In principle, there will be an increase in the anti-proliferative activity of the fractionated extracts (ethyl acetate, $t$-butanol and aqueous extracts) compared to the crude methanol extract if there is any significant amount of antiproliferative compounds present in the methanol extract. However, this was not found in this study. The fractionated extracts (ethyl acetate, $t$-butanol and aqueous extracts) also did not show significantly lower anti-proliferative activities than the crude methanol extract. This implies that any synergistic effect among the components present in the crude methanol extract leading to its anti-proliferative activity is unlikely [8]. It was also noted that all the stem extracts of Pereskia bleo had higher antiproliferative activities against the normal mouse fibroblast cells (NIH/3T3) than the mouse mammary cancer cells (4T1).

Previous study on this plant by Tan et al. (2005) showed that the crude methanol extract of the combined stems and leaves of Pereskia bleo possessed promising anti-proliferative activity with $\mathrm{IC}_{50}$ of $2.0 \mu \mathrm{g} / \mathrm{mL}$ against the human mammary cell line, T47-D [2]. The difference between this reported value and those obtained in the present study could not be solely due to the use of different cell lines in both studies. It is to be noted that the cells were treated with the methanol extract in culture media containing only $0.5 \%$ foetal bovine serum in the study by Tan et al. [2]. It is known that serum contained in culture media plays a vital role in cell survival and proliferation. It can also protect cells against apoptosis [9]. It has been reported that the lysophospholipids in serum can prevent apoptosis via the prevention of tumour necrosis factor-related apoptosis-inducing ligand and the Bad molecule (a pro-apoptotic molecule) phosphorylation [10]. Under a sub-optimal condition where the culture medium contains only $0.5 \%$ foetal bovine serum, a higher level of natural apoptotic cell death can occur.

In this study, it was found that some of the stem extracts resulted in a statistically significant enhancement of the growth of the mouse mammary cancer cells (4T1), particularly when the cells were incubated with these extracts for 24 hours. The enhancement of the growth of the 4T1 cells may be due to bio-active compound(s) in the extracts that could promote or regulate cell division. Less enhancement of the growth of the 4T1 cells was observed at longer incubation periods of 48 and 72 hours. This may be explained by the gradual depletion of nutrients in the culture media with longer incubation period, which subsequently led to a slower cell growth. The ability of the stem extracts to enhance the growth of the 4T1 cells should be further investigated, as it seems to imply that the extracts may be contraindicated in cancer patients as they may have the potential to enhance the growth of the cancer cells in these patients.

In this study, the antioxidant activities of the methanol, ethyl acetate, $t$-butanol and aqueous extracts of the stems of Pereskia bleo were measured by their ability to scavenge the ABTS radical cations. Upon fractionation of the crude methanol extracts of the stems of Pereskia bleo, it was found that the antioxidant components were concentrated in the fractionated $t$-butanol extracts, followed by the ethyl acetate extracts. The methanol extract possessed higher antioxidant activity than the aqueous extract.

The antioxidant capacities of the $t$-butanol extract, i.e. the fraction that had the highest antioxidant properties among the extracts, were $450 \mu$ mole Trolox Equivalent per gram dry weight. This is similar to or less than those of commercial black teas and green teas which have antioxidant capacity ranging between $235 \mu$ mole Trolox Equivalent per gram dry weight and $1526 \mu$ mole Trolox Equivalent per gram dry weight [6]. The antioxidant effect of the Pereskia bleo stem extract is also much less than that of Vitamin C, a known antioxidant compound, which has an antioxidant capacity of 5158 Trolox Equivalent per gram dry weight.

Treatment of the normal mouse fibroblast cells (NIH/3T3) with the stem extracts of Pereskia bleo for 24 hours resulted in a lower level of apoptosis in the cells compared to that occurring in the non extracttreated cells grown under the same conditions. The results indicated that all the methanol, ethyl acetate, $t$-butanol and aqueous extracts of the stems of Pereskia bleo had the ability to protect the NIH/3T3 
cells against natural programmed cell death by apoptosis. The protective effects were more obvious at $50 \mu \mathrm{g} / \mathrm{mL}$ compared to $100 \mu \mathrm{g} / \mathrm{mL}$ of the extracts. The higher level of apoptosis at the higher extract concentration was not unexpected as the antiproliferative assay on the extracts demonstrated a gradual decrease in cell viability with increasing extract concentration. Amongst the stem extracts tested, the ethyl acetate extract showed the highest apoptosis-limiting activity.

All the fractionated extracts of the stems of Pereskia bleo showed higher apoptosis-limiting activities than the crude methanol extract, except the aqueous extract. This suggested that the crude methanol extract contained bioactive component(s) that could protect the normal mouse fibroblast cells against natural apoptotic cell death, and these components could be concentrated by fractionating the crude methanol extract.

The protective effects of the stem extracts of Pereskia bleo against oxidant-induced cell death were also evaluated by pre-treating the NIH/3T3 cells with the extracts before the oxidant, 2,2-Diphenyl-1Picrylhydrazyl (DPPH), was added. All the extracts were able to limit oxidant-induced cell death. The ability to limit oxidant-induced cell death was not significantly different between $50 \mu \mathrm{g} / \mathrm{mL}$ and 100 $\mu \mathrm{g} / \mathrm{mL}$ of the extracts, probably because the maximum effective concentration had been reached in the assays. The findings on the protective effects of the extracts against oxidant-induced cell death were consistent with the moderate antioxidant activities of the extracts determined by the ABTS radical cation scavenging assay. The extracts were able to scavenge some the DPPH radicals introduced and thus the cells were less susceptible to the damaging effect of the DPPH radicals.

\section{CONCLUSIONS}

From this study, it can be concluded that all of the crude methanol and fractionated ethyl acetate, $t$ butanol and aqueous extracts of the stems of Pereskia bleo do not have significant anti-proliferative effect on both the mouse mammary cancer cells (4T1) and the normal mouse fibroblast cells (NIH/3T3). They are not cytotoxic, based on the criterion that a crude extract should have an $\mathrm{IC}_{50}$ of less than $20 \mu \mathrm{g} / \mathrm{mL}$ for it to be considered cytotoxic against the treated cells [7]. The extracts are also not significantly selective in inhibiting the proliferation of the mouse mammary cancer cells compared to the normal mouse fibroblast cells. The findings in this study do not support the general belief among the ethnic groups in Malaysia that the plant possesses anti-cancer properties. The ability of some of the extracts to enhance the growth of the mouse mammary cancer cells under certain conditions is of concern and needs to be further investigated as this may imply that the plant is contraindicated in cancer patients. Among the extracts tested, the $t$-butanol extracts of the stems of Pereskia bleo possess the highest antioxidant property. However, the antioxidant capacity is only considered moderate when compared to other known antioxidant substances such as green tea leaves and vitamin C. The ability of the extracts of the stems of Pereskia bleo in limiting natural and oxidant-induced cell death in normal mouse fibroblast cells suggests that the plant may have prophylactic property. In conclusion, this study highlights the importance of systematic scientific research in the ethnopharmacological study of natural products to ensure their efficacy and safety.

\section{ACKNOWLEDGEMENTS}

We would like to thank Taman Pertanian Malaysia, Universiti Putra Malaysia, for kind donation of the Pereskia bleo plant. We are grateful to Dr E. Soepadmo from the Forest Research Institute of Malaysia for his assistance in the identification of this plant. This work was supported by a grant from the International Medical University.

\section{REFERENCES}

1. Goh K.L. (2000). Malaysian Herbaceous Plants. Millennium Edition, Advanco Press, Malaysia.

2. Tan M.L., Sulaiman S.F., Najimuddin N., Samian M.R., Tengku Muhammad T.S. (2005). Methanolic extract of Pereskia bleo (Kunth) DC. (Cactaceae) induces apoptosis in breast carcinoma, T47-D cell line. Journal of Ethnopharmacology 96: 287-294.

3. Abd Malek S.N., Abdul Wahab N., Yaacob H., Sim K.S., Hong S.L., Lee G.S., Rahman S.N.S.A. (2008). Cytotoxic activity of Pereskia bleo (Cactaceae) against selected human cell lines. International Journal of Cancer Research 4(1): 20-27.

4. Er H.M., Cheng E., Radhakrishnan A.K. (2007). Anti-proliferative and mutagenic activities of aqueous and methanol extracts of leaves from Pereskia bleo (Kunth) DC (Cactaceae). Journal of Ethnopharmacology 113: 448-456.

5. Carmichael J., DeGraff W.G., Gazdar, A.F., Minna, J.D., Mitchell, J.B. (1987). Evaluation of a tetrazolium-based semiautomated colorimetric assay: assessment of radiosensitivity. Cancer Research 47: 943-946. 
6. Re R., Pellegrini N., Proteggente A., Pannala A., Yang M., Rice-Evans C. (1999). Antioxidant activity applying an improved ABTS radical cation decolorization assay. Free Radical Biology \& Medicine 26(9): 1231-1237.

7. Geran R.I., Greenberg N.H., Macdonald M.M., Schumacher A.M., Abbott B.J. (1972). Protocols for screening chemical agents and natural products against animal tumours and other biological system. Cancer Chemotherapy reports 3: 59-61.

8. Shao Z.H., Vanden-Hoek T.L., Li C.Q., Schumacker P.T., Becker L.B., Chan K.C., Qin Y., Yin J.J., Yuan C.S. (2004). Synergistic effect of Scutellaria baicalensis and grape seed proanthocyanidins on scavenging reactive oxygen species in vitro. Am J Chin Med 32(1): 89-95

9. Aoki M., Morishita R., Matsushita H., Nakano N., Hayashi S., Tomita M., Yamamoto K., Moriquchi A., Higaki J., Ogihara T. (1997). Serum deprivation-induced apoptosis accompanied by up-regulation of p53 and bax in human aortic vascular smooth muscle cells. Heart vessels 12: 71-75.

10. Kang Y.C., Kim K.M., Lee K.S., Namkoong S., Lee S.J., Han J.A., Jeoung D., Ha K.S., Kwon Y.G., Kim Y.M. (2004). Serum bioactive lysophospholipids prevenrts TRAIL-induced apoptosis via PI3K/Akt-dependent cFLIP expression and Bad phosphorylation. Cell Death and Differentiation 11: 1287-1298. 
Malaysian Journal of Science 28 (3): 225- 239 (2009) 